\title{
Cleaning of Sendai Virus-infected Mice by Embryo Transfer Technique
}

\author{
Masanori OKAMOTO, Satoru MATSUSHITA, and \\ Tsuneya MATSUMOTO \\ National Institute of Radiological Sciences, \\ 4-9-1 Anagawa, Chiba-shi 260, Japan
}

(Received 13 April 1990/Accepted 19 June 1990)

\begin{abstract}
Mouse embryos (8-16 cells) were collected from Sendai virus (SV)-infected mice at 5 or 7 weeks after inoculation. All donors having embryo(s) were positive when tested by CF test or ELISA for SV antibody at the time of embryo collection. Most of the morphologically normal embryos developed $(90.6 \%, 259 / 286)$ to morulae or blastocysts after culture for $26-28 \mathrm{hr}$. A total of $76 \mathrm{embryos}$ cultured were transferred to the uteri of SV-free pseudopregnant recipients. Forty-seven young were obtained from these recipients ( $61.8 \%$ of development rate) and 46 young were successfully reared up to 10 th week of age. All the recipients and the young were negative by testing SV antibody. These results indicate that the embryo transfer technique is useful for cleaning of SV-infected mice.
\end{abstract}

\section{胚移植法を用いたセンダイウイルス感染マウスの清浄化}

岡本正則·松下悟・松本恒弥

\section{放射線医学棇合研究所}

肧移植技術は, 発生工学の分野において人為操作を加 えた受精卵を個体へ発生させるための重要な技術である [11]。また本技術は病原微生物に感染した動物からの垂 直感染を防御し，病原微生物を除去する手段としても有 用であることが知られている [3]。マウスについて，也 ンダイウイルス (Sendai virus : SV) およびマウス肝 炎ウイルス, パスッレラによる感染マウスの清浄化を行 った報告 $[1,2,8]$ がある。

著者らの研究所では, これまでに数回研究上の必要性 から，SV 抗体陽性のマウスを導入せざるを得ない場合 があった。SV 感染症に批いては血中の抗体が上昇する のに伴い，体内よりウイルスが消失すると考えられてい る[4,7]。しかし抗体の上昇にもかかわらず，ウイルス核 酸が検出されるとする報告もあり [6]，抗体上昇後の感 染性ウイルスの存在は完全に否定できない。このため,
我々は外部から種動物として導入した近交系マウスは, SV を含む各種微生物抗体検出の有無にかかわらず，一 度子宮切断術による清浄化処置を施した後に, 清浄飼育 施設において生産に供する方式をとっている。しかし子 宮切断術法による清净化は微生物の種類により必ずしも 確実とはいえず，生産効率む低いといら久点を持ってい る。本研究では, 従来の子宮切断術法に代わる肧移植法 について, SV 抗体陽性マウスの清浄化に批るる効率性 について検討した。

動物：ドナーマウスは, Jcl：MCH (ICR)（日本ク レア, SV-free のSPF) の雙マウスを使用した。交配 用の雄打よび精管結紫雄マウスについても同系を用い た。肧移植用のレンピェントマウスには, 当所生産の (C57BL/ $6 \mathrm{JNrs} \times \mathrm{C} 3 \mathrm{H} / \mathrm{HeMsNrs}) \mathrm{F}_{1}$ (SV-free の SP F)を用いた。 
SV 感染：ドナーは， 7 週路時にエーテル軽麻酔下で, 鼻孔に $10^{3.5} \mathrm{TCID}_{50}\left(10^{3.5}\right.$ Tissue culture $50 \%$ infectious doses）/20 $\mu \mathrm{l} /$ 匹の SV（M-73株, 国立予研獣 疫部鈴木映子博士より分与された）浮遊夜を接種した。 接種後, 臨床症状を観察するとともに経時的に体重測定 を行った。そこで，スナッフル，立毛の症状を示し，接 種前より有意に体重の减少した個体を感染の成立したも のと判定し、胚採取用に供した。

肧採取：ドナーの過剩排卵誘起および肧採取法は, Yokoyama 5 [10］の方法に準じた。すなわち，SV 接種後 5 または 7 週目に PMSG, hCG 各々 $5 \mathrm{IU}$ を 48 時 間間隔で腹腔内注射し，排卵誘起を行った。hCG 注射 後に同系の雄と交配し, 臸栓を確認（妊娠第 1 日目）し た個体は，第 3 日目に卵管，子宮を灌流し，8～16細胞 期胚を採取した。形態的に正常な泼は, 修正 Whitten 培 養液 [9]内で, $26 \sim 28$ 時間体外培養 $\left(37^{\circ} \mathrm{C}, 5 \% \mathrm{CO}_{2}, 95\right.$ \%空気）を行った。

肧移植：培養後，正常に発生した桑実胚および胚盤胞 は偽妊娠（精管結禁雄との不妊交尾により誘起）第 3 日 目のレンピエント（12〜13週齡）の子宮に移植した。産 子は生後 10 週路時まで㕕成した。

微生物学検査 : SV 感染の有無を検査する目的で，接 種したドナーは肧採取時に，またレンピエントおよび産 子は生後10週秢時に, 各々剖検を行うとともに補体結合 (CF) 反応, 免疫酵素抗体 (ELISA) 法により, 血清中 の抗体価の測定を行った。

飼育管理 : SV 接種前の個体は清浄動物飼育装置（明 文館製）内, 接種後は感染動物飼育装置（トキワ製）内 で飼育した。胈移植後のレンピエントは, 隇菌済の感染 動物飼育装置内で維持した。なお減菌後の本装置内は, 事前の検討でSPF. 状態を保持していることが確認され
ている。

SV 感染マウスより採取した正常肧の数および体外培 養後の発生成績を Table 1 に示した。SV 接種後のマ ウスの生存率は, 実験 I が50.0\%, 実験 II った。SV 感染マウスの過㮃排卵誘起後の臸栓形成率 (81.0\%，17/21）は, 同系のSPF マウスによる結果 [5]と比較しても, 高い值であった。これら17匹のマウ スより計286個の胚を採取した。マウス 1 匹当たりの正 常肧数の平均值は16.8個となった。この内, 培養後に正 常な桑実胚または胚盤胞に発生した胚の場合は，90.6\% （259/286）と高值を示した。胚採取したドナー（17匹）は SV の抗体価の測定を行い, 全ての検体が20 80倍のCF 抗体価を示し，感染の成立していたことが確認された。

SV 感染マウスから採取し，培盖後に桑実胚または胚 盤胞に発生した胚の移植成績を Table 2 に示した。76 個の胚は 9 匹のレシピエントに移植し， 8 匹が妊娠し た。その結果, 移植肧総数の $61.8 \%$ に当たる 47 匹の産子 を得た。妊娠したレンピエントの内，7匹は妊娠第20日 までに自然分婏（産子45匹）をしたが，残り1匹は妊娠 第20日目に子宮切断術を行い，2 元の子を得た。これら の子は同一実験群のレシピェントを里親として, 哺育さ せた。47匹の産子は全例が離乳した。離乳直後に 1 匹は 死亡したが，46匹は生後10週齢まで育成した。分婏した レシピェント（８匹）および移植による子（46匹）の血 清中から，CF 反応および ELISA 法のいずれにおいて もSV抗体は検出されなかった（Table 2)。剖検でも， $\mathrm{SV}$ 感染を疑わせる病変は認められなかった。なお䏍成 中に死亡した 1 例についても, 剖検で感染性の病変は認 められなかった。

以上の結果から，十分に抗体価が上㫒した SV 感染、 ウスから肧を採取し, SPFマウスに移植することによ

Table 1. Number of embryos collected from Sendai virus-infected mice and development of embryos after culture for $26-28 \mathrm{hr}$

\begin{tabular}{|c|c|c|c|c|c|c|}
\hline Exp. no. & $\begin{array}{l}\text { No. of } \\
\text { animals } \\
\text { inoculated }\end{array}$ & $\begin{array}{l}\text { No. of animals } \\
\text { survived after } \\
\text { infection } \\
\qquad(\%)\end{array}$ & $\begin{array}{l}\text { No. of animals } \\
\text { treated with } \\
\text { PMSG-hCG }\end{array}$ & $\begin{array}{l}\text { No. of animals } \\
\text { having embryo(s) } \\
\qquad(\%)\end{array}$ & $\begin{array}{l}\text { No. of } \\
\text { morphologically } \\
\text { normal embryos } \\
\text { collected }^{* *}\end{array}$ & $\begin{array}{l}\text { No. of embryos } \\
\text { developed to } \\
\text { morula or blastocyst*** } \\
\qquad(\%)\end{array}$ \\
\hline I & 10 & $5^{\mathrm{a}}(50.0)$ & $5^{a}$ & $5(100)$ & 32 & $28(87.5)$ \\
\hline II & 31 & $29^{b}(93.5)$ & $16^{\mathrm{b}}$ & $12(75.0)$ & 254 & $231(90.9)$ \\
\hline Total & 41 & $34 \quad(82.9)$ & 21 & $17(81.0)$ & 286 & $259(90.6)$ \\
\hline
\end{tabular}

a : At 5 weeks after inoculation b : At 7 weeks after inoculation * : Animals with vaginal plug after mating $\quad{ }^{* *}: 8-16$ cell stages on day 3 (discovery of vaginal plug is taken as day 1 ) ${ }^{* * *}$ : Morphologically normal embryos after culture for $26-28 \mathrm{hr}$ in vitro 
Table 2. Development of embryos collected from Sendai virus (SV)-infected mice after transfer to pseudoprgnant recipients

\begin{tabular}{|c|c|c|c|c|c|c|c|}
\hline \multirow[b]{2}{*}{ Exp. no. } & \multirow{2}{*}{$\begin{array}{l}\text { No. of } \\
\text { embryos } \\
\text { transferred }\end{array}$} & \multirow{2}{*}{$\begin{array}{l}\text { No. of pregnant } \\
\text { recipients/No. of } \\
\text { recipients }\end{array}$} & \multicolumn{3}{|c|}{ No. of live young } & \multirow{2}{*}{$\begin{array}{l}\text { No. of } \\
\text { young } \\
\text { weaned } \\
\left(: 0^{7}\right)\end{array}$} & \multirow{2}{*}{$\begin{array}{l}\text { No. of SV positive/No. } \\
\text { of young tested }{ }^{* * *}\end{array}$} \\
\hline & & & $\begin{array}{l}\text { Total } \\
(0 ; 0)^{*}\end{array}$ & born & $\begin{array}{l}\text { caesarean- } \\
\text { derived }^{* *}\end{array}$ & & \\
\hline $\mathrm{I}$ & 5 & $1 / 1$ & $5(100)$ & 5 & 0 & $5(3: 2)^{* * *}$ & $0 / 4$ \\
\hline II & 71 & $7 / 8$ & $42(59.2)$ & 40 & 2 & $42(24: 18)$ & $0 / 42$ \\
\hline Total & 76 & $8 / 9$ & $47(61.8)$ & 45 & 2 & $47(27: 20)$ & $0 / 46$ \\
\hline
\end{tabular}

り，清浄なマウスを作出できることが示された。なお， 胚移植による SV 感染マウスの清浄化に関し, Carthew ら［1］は接種後 1 週間を経過したドナーより肧採取を 行い, レシピエントに移植して清浄な産子を得ている。

病原微生物に感染したマウスを清浄化する方法とし て，子宮切断術法が広く用いられている。しかしこの方 法は, 垂直感染を起こす病原微生物では手術時に胎子へ の感染がすでに成立していることがあるので, 確実性に 乏しい。また, 手術を行5時期の早い場合に胎子の発育 が不十分で蘇生しないことや, 里親哺育が成功しないこ となどがあるので効率的とはいえない。当研究所に拈け る昨年の実績では, 子宮切断術の成功率および蘇生し里 親哺育を試みた子の数に対する離乳子の割合は, 各々 18.2\%（2例/11例)，15.3\%（9匹/59匹）であり低い のが実状である。これに対して本研究の臕移植法は, 成 功率および移植胚数に対する離乳子の割合が, 各々 88.9 \%（8/9）执よび60.5\%（46/76）と高くなった（Table 2)。胚移植法は従来の子宮切断術法に比べて簡便で効率 的であり，とくに生産っロニーにおいては実用性が高い と考えられる。今後は SV 感染マウスの清浄化を行ら方 法として, 肧移植法が実用上有効な手段の一つになると 思われる。

\section{要約}

$\mathrm{SV}$ 感染マウス（ドナー）から, ウイルス接種後 5 ま たは 7 週目に胚を採取し, SV 抗体陰性の SPFレシピ エントに移植した。ドナーは血清の SV 抗体の検查によ り, 全例が陽性を示し, 感染が成立していた。ドナー 17 匹より計286個の正常胚を得て，培養後に桑実肧または 胚盤胞に発生した胚は259個（90.6\%）であった。76個
の胚を 9 匹のレシピェントに移植し，8匹が妊娠・分婏 した。移植した胚の $61.8 \%$ に当たる47匹が産子へ発生し た。レシピェント扣よび産子は血清の SV 抗体の検査に おいて, 全例, ともに陰性を示した。以上より，抗体陽性 の SV 感染マウスは, SPF のレシピェントに肧移植を行 い, 清浄なマウスの作出の可能なことが明らかとなった。

本研究に当たり，センダイウイルス株を分与して下さった国 立予研獣疫部鈴木映子博士, 胚培養と移植につき研修させてい ただけ（財）実験動物中央研究所野村達次所長, 横山等介室 長ならびに校閲の労をとられ，有益な助言をいたたいた東京大 学医科学研究所豊田裕教授に対し感謝いたします。

\section{文献}

[1] Carthew, P., Wood, M. J., and Kirby, C. (1983). J. Reprod. Fert., 69, 253-257.

[2] Carthew, P., Wood, M. J., and Kirby, C. (1985). J. Reprod. Fert., 73, 207-213.

[3] Eaglesome, M. D., Hare, W. C. D., and Singh, E. L. (1980). Can Vet. J, 21, 106-112.

[4] Iwai, H. and Itoh, T. (1982). Exp. Anim, 31, 129133.

［5] 小島博子・横山峯介 (1985)。 $\mathrm{MCH}$ 動物データ集, pp. 13-16, MCH 動物研究連絡会編, 日本クレア, 東京.

[6] Koch, E. M., Neubert, W. J., and Hofshneider, P. H. (1984). Virogy, 136, 78-88.

[7] Parker, J. C. and Reynolds, R. K. (1968). Am J. Epidemiol, 88, 112-125.

[8] Reetz, I. C., Wullenweber-Schmidt, M., Kraft, V., and Hedrich, H.-J. (1988). Lab. Anim Sci, 38, 696701 .

[9] Whitten, W. K. (1971). Adv. Biosci, 6, 129-141.

[10] Yokoyama, M., Wakasugi, N., and Nomura, T.(1981). In Proceeding of the Workshop on Embryo Storage and Banking in Laboratory Animals, pp. 113-117, G. H. Zeilmaker (ed.), Gustav Fisher Verlag, Stuttgart, New York.

[11］横山篻介・勝木元也・野村達次 (1988). 実験医学, 6, 246-251. 